\title{
SCRG1 suppresses LPS-induced CCL22 production through ERK1/2 activation in mouse macrophage Raw264.7 cells
}

\author{
MANABU INOUE ${ }^{1,2}$, JUNKO YAMADA $^{1,3}$, EMIKO AOMATSU-KIKUCHI $^{1,3}$, \\ KAZURO SATOH $^{3}$, HISATOMO KONDO ${ }^{2}$, AKIRA ISHISAKI ${ }^{1}$ and NAOYUKI CHOSA ${ }^{1}$ \\ ${ }^{1}$ Division of Cellular Biosignal Sciences, Department of Biochemistry, Iwate Medical University, Yahaba, \\ Iwate 028-3694; ${ }^{2}$ Department of Prosthodontics and Oral Implantology, and ${ }^{3}$ Division of Orthodontics, Department of \\ Developmental Oral Health Science, Iwate Medical University School of Dentistry, Morioka, Iwate 020-8505, Japan
}

Received October 21, 2016; Accepted April 6, 2017

DOI: $10.3892 / \mathrm{mmr} .2017 .6492$

\begin{abstract}
Recently, we identified the scrapie responsive gene 1 (SCRG1) secreted from mesenchymal stem cells (MSCs) and its receptor bone marrow stromal cell antigen 1 (BST1) as positive regulators of stem cell qualities such as self-renewal, migration abilities, and osteogenic differentiation potential. Here, we examined the effect of the paracrine activity of SCRG1 in macrophages. The mouse macrophage-like cell line Raw264.7 expressed BST1/ $\beta 1$ or BST1/ $\beta 2$ integrin as possible SCRG1 receptors. Unexpectedly, recombinant SCRG1 did not enhance cell proliferation, migration, or adhesion in these macrophages. However, further examination of the effect of SCRG1 in Raw264.7 cells did reveal a potent anti-inflammatory effect whereby SCRG1 suppressed LPS-induced CCL22 production. SCRG1 also induced the phosphorylation of extracellular signal-regulated kinase 1/2 (ERK1/2) in these cells and, moreover, a mitogen-activated protein kinase (MAPK)/ERK kinase inhibitor U0126 significantly suppressed the effect of SCRG1 on LPS-induced chemokine CCL22 production. Taken together, these data indicate that SCRG1 signals through the MAPK pathway and suppresses the LPS signaling pathway. CCL22 is generally known to be chemotactic for monocytes, dendritic cells, natural killer cells and chronically activated $\mathrm{T}$ lymphocytes, suggesting that MSC-derived SCRG1 may block infiltration of these cells. A mechanism is proposed by which MSCs play their immunosuppressive role through suppressing chemokine expression in monocyte/macrophage lineage cells.
\end{abstract}

Correspondence to: Dr Naoyuki Chosa, Division of Cellular Biosignal Sciences, Department of Biochemistry, Iwate Medical University, 2-1-1 Nshitokuta, Yahaba, Iwate 028-3694, Japan

E-mail: nchosa@iwate-med.ac.jp

Key words: scrapie responsive gene 1, mesenchymal stem cells, CC-chemokine ligand 22, extracellular signal-regulated kinase 1/2, macrophage

\section{Introduction}

Mesenchymal stem cells (MSCs) are adult stem cells with the ability to differentiate into mesenchymal tissue cells while retaining self-renewal and migration abilities (1). Many recent studies have revealed that MSCs possess immunomodulatory functions that they exert through cell-to-cell contacts, as well as by secreting growth factors, cytokines, and chemokines $(2,3)$. The effect of immunosuppression with MSCs has been reported in graft-versus-host disease (4) and multiple system atrophy (5). MSCs have the ability to migrate to damaged tissue by inducing peripheral tolerance by inhibiting the release of pro-inflammatory cytokines (2). The advantages of MSC-based cell therapy have been demonstrated in acute lung injury (6), myocardial infarction (7), acute renal failure (8), cerebral ischemia (9) and Alzheimer's disease (10). At the cellular level, it has been shown that MSCs can directly inhibit both $\mathrm{T}$ lymphocyte and microglial cell proliferation and can negatively modulate the cytokine-secretion profile of dendritic cells and monocytes/macrophages (11-14).

In our recent study, we identified the scrapie responsive gene 1 (SCRG1) secreted from MSCs and its receptor complex bone marrow stromal cell antigen 1 (BST1)/ $\beta 1$ integrin, as positive regulators of stem cell qualities (15). SCRG1, which was identified by Dron et al as a protein that increased expression in the brain of scrapie infected mice, was shown to be associated with neurodegenerative changes in transmissible spongiform encephalopathy, as well as in brain injury, and is associated with autophagy (16-18). The SCRG1 gene encodes a 98-amino acid, cytokine-like peptide with an N-terminal signal peptide $(19,20)$. Intriguingly, in stem cells SCRG1 was shown to maintain octamer-binding transcription factor 4 (Oct-4) and CD271/low-affinity nerve growth factor receptor (LNGFR) expression and thereby maintain the MSC's potential for self-renewal, migration abilities, as well as osteogenic differentiation potential, even at high stem cell passage numbers (15). Other cytokines and chemokines secreted from MSCs have been implicated in immunosuppression and repair of damaged tissues (21-24). MSC differentiation along different pathways is regulated by stimulation with various growth factors, cytokines, or chemokines, as has been demonstrated in the differentiation of bone marrow-derived MSCs $(25,26)$. 
SCRG1 secreted from MSCs is predicted to affect a variety of cell types in vivo. In this study, we hypothesized that SCRG1 secreted into the extracellular space by MSCs exhibits paracrine activity. To explore this possibility, we examined the paracrine effect of MSC-derived SCRG1 on the immune response of Raw264.7 macrophages. In particular, as a readout of macrophage function, we focused on macrophage production of CC-chemokine ligand 22 [CCL22; also known as MDC (macrophage-derived chemokine)], which is known to display chemotactic activity for monocytes, dendritic cells, natural killer cells, and chronically activated T lymphocytes (27-30).

\section{Materials and methods}

Reagents. Recombinant mouse SCRG1 (rmSCRG1), expressed in yeast, was purchased from MyBiosource, Inc. (MBS1177239, San Diego, CA, USA). The MAPK/ERK kinase inhibitor U0126 was purchased from Calbiochem (Merck Millipore, Darmstadt, Germany). Lipopolysaccharide (LPS) derived from Escherichia coli 0111:B4 was purchased from Sigma-Aldrich (St. Louis, MO, USA).

Cell culture. Mouse macrophage-like Raw264.7 cells (American Type Culture Collection, Manassas, VA, USA) were maintained in minimum essential medium Eagle's $\alpha$-modification ( $\alpha$ MEM) (Sigma-Aldrich) supplemented with $10 \%$ fetal bovine serum (FBS) (HyClone, GE Healthcare Life Sciences, Logan, UT, USA) under the condition of $5 \% \mathrm{CO}_{2}$ at $37^{\circ} \mathrm{C}$.

Proliferation assay. Cell proliferation was analyzed by WST-1 assay reagent (Roche Diagnostics, Basel, Switzerland) according to the manufacturer's instructions. Raw264.7 cells were cultured on 96-well plates (Nunc; Thermo Fisher Scientific, Waltham, MA, USA) in $100 \mu \mathrm{l}$ complete medium containing with or without $100 \mathrm{ng} / \mathrm{ml} \mathrm{rmSCRG1.} \mathrm{After} \mathrm{five}$ days, the cells were added with $10 \mu \mathrm{l}$ WST-1 reagent and incubated for $1 \mathrm{~h}$. The absorbance was measured using an MPR-A4i microplate reader (Tosoh Corp., Tokyo, Japan) at $450 \mathrm{~nm}$.

Migration assay. The migration assay was performed using $8-\mu \mathrm{m}$ pore sized Transwell cell culture inserts (BD Biosciences, Franklin Lakes, NJ, USA). Raw264.7 cells $\left(1.0 \times 10^{5}\right)$ were seeded on the upper well in $350 \mu 1$ serum-free $\alpha$ MEM containing $0.1 \%$ BSA (Sigma-Aldrich). The lower well was filled in $600 \mu \mathrm{l}$ complete medium containing with or without $100 \mathrm{ng} / \mathrm{ml} \mathrm{rmSCRG1.} \mathrm{After} \mathrm{incubation} \mathrm{for} 6 \mathrm{~h}$, cells that had not migrated were scraped off with a cotton swab. The number of cells migrated to the lower side of the filter was stained with Diff-Quik Three-Step Stain Set (Sysmex, Kobe, Japan), and then counted using a microscope (Olympus IX70; Olympus Corp., Tokyo, Japan) under five high-power fields (x400 magnification).

Adhesion assay. Raw264.7 cells $\left(1.0 \times 10^{5}\right)$ were seeded onto a fibronectin-coated culture dish (BD Biosciences) and cultured in complete medium with or without $100 \mathrm{ng} / \mathrm{ml} \mathrm{rmSCRG1.}$ After $6 \mathrm{~h}$, non-adhered cells on the bottom of the dish were removed by washing twice with phosphate-buffered saline
(PBS). The number of cells adhered to the culture dish were measured by the WST-1 assay described above. The absorbance of the dye in the culture directly correlates with the number of live cells.

Reverse transcription-quantitative polymerase chain reaction (RT-qPCR). Raw264.7 cells were either left unstimulated or

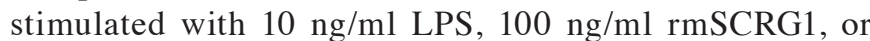
$10 \mathrm{ng} / \mathrm{ml}$ LPS plus $100 \mathrm{ng} / \mathrm{ml} \mathrm{rmSCRG1}$ in the absence and presence of $1 \mathrm{mM} \mathrm{U} 0126$, for $6 \mathrm{~h}$. Total RNA extraction, cDNA synthesis, RT-qPCR were performed with methods of our previous study (15). Expression of $\mathrm{Ccl} 22$ was normalized to glyceraldehyde-3-phosphate dehydrogenase (Gapdh). The following primer pairs were used; $C c l 22$ (sense, 5'-GGCACCT ATCCAGTGCCACA-3' and antisense, 5'-TGGTGGACCAGC CTGAAACTC') and Gapdh (sense, 5'-TGTGTCCGTCGTGG ATCTGA-3' and antisense, 5'-TTGCTGTTGAAGTCGCAG GAG-3'). Relative expression levels were calculated by the $2^{-\Delta \Delta \mathrm{Cq}}$ method (31) as a fold-increase or -decrease.

Primer array. Raw264.7 cells were stimulated with $10 \mathrm{ng} / \mathrm{ml}$ LPS, $100 \mathrm{ng} / \mathrm{ml} \mathrm{rmSCRG1}$, or $10 \mathrm{ng} / \mathrm{ml}$ LPS plus $100 \mathrm{ng} / \mathrm{ml}$ rmSCRG1 for $6 \mathrm{~h}$. Unstimulated cells were used as a control. Gene expression levels of a range of cytokines and chemokines were measured using a PrimerArray consisting of mouse cytokines and cytokine receptors (PN001, Takara Bio) and PrimerArray Analysis Tool version 2.0 (Takara Bio) according to the manufacturer's instructions. Genes whose expression levels increased more than 100-fold following LPS stimulation and less than 100-fold following SCRG1 treatment were identified.

Western blotting. Raw264.7 cells were serum-starved overnight and stimulated with $100 \mathrm{ng} / \mathrm{ml} \mathrm{rmSCRG1} \mathrm{for} \mathrm{various}$ period time. Western blotting was performed in our previously reported procedure (15). The following primary antibodies that has been purchased from Cell Signaling Technology (Danvers, MA, USA) were used; anti-p44/42 mitogen-activated protein kinase (ERK1/2), anti-phospho-ERK1/2, anti-c-Jun N-terminal kinase (JNK), anti-phospho-JNK, anti-p38, anti-phospho-p38, anti-Akt, anti-phospho-Akt, anti-focal adhesion kinase (FAK), anti-phospho-FAK. $\beta$-actin level measured were detected with an anti- $\beta$-actin antibody (Santa Cruz Biotechnology, Dallas, TX, USA) as a loading control. The densitometry of the band measured by ImageJ version 1.44 software was expressed as the ratio of phosphorylation to the total molecule.

Enzyme-linked immunosorbent assay (ELISA). Raw264.7 cells were left unstimulated or were stimulated with $10 \mathrm{ng} / \mathrm{ml} \mathrm{LPS}$, $100 \mathrm{ng} / \mathrm{ml} \mathrm{rmSCRG1}$, or $10 \mathrm{ng} / \mathrm{ml}$ LPS plus $100 \mathrm{ng} / \mathrm{ml} \mathrm{rmSCRG1}$ for $48 \mathrm{~h}$. The amount of secreted CCL22 in the culture medium was measured using a sandwich ELISA kit for mouse CCL22 (R\&D Systems, Inc., Minneapolis, MN, USA). CCL22 levels were quantified according to the manufacturer's instructions.

Flow cytometry. A total of $1 \times 10^{5}$ Raw 264.7 cells suspended in PBS containing $2 \mathrm{mM}$ EDTA and $0.5 \%$ FBS were incubated with either a phycoerythrin (PE)-conjugated anti-mouse BST1/CD157 (1:10), anti-mouse $\beta 1$ integrin/CD29 (1:10), or anti-mouse $\beta 2$ integrin/CD18 (1:10) (all from BioLegend, Inc., 

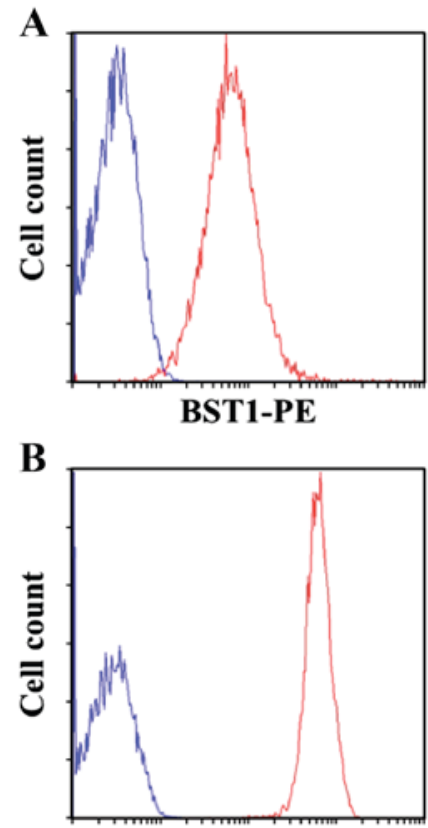

$\beta 1$ integrin-PE

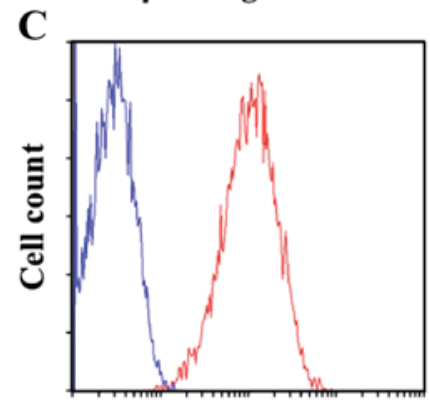

$\beta 2$ integrin-PE

Figure 1. Raw264.7 cells express the bone marrow stromal cell antigen 1 (BST1), $\beta 1$ integrin, and $\beta 2$ integrin as a scrapie responsive gene 1 (SCRG1) receptor complex. Cell surface expression of BST1 (A), $\beta 1$ integrin (B), and $\beta 2$ integrin $(C)$ was analyzed by flow cytometry with phycoerythrin (PE)-conjugated specific antibodies. Specific antibody staining (red) and isotype control $\mathrm{IgG}$ staining (blue) are shown.

San Diego, CA, USA) antibody for $1 \mathrm{~h}$ at $4^{\circ} \mathrm{C}$. Data acquisition and analysis was performed using a flow cytometer EPICS XL (Beckman Coulter, Brea, CA, USA).

Statistical analysis. All experiments were performed in triplicate. Numerical data were presented as the mean \pm standard deviation (SD), and significant differences were analyzed by Student's $t$-test. $\mathrm{P}<0.05$ were considered statistically significant.

\section{Results}

Raw264.7 cells express BST1, and $\beta 1$ and $\beta 2$ integrins as an SCRG1 receptor complex. Our recent study revealed that SCRG1 secreted from MSCs forms a complex with the membrane proteins BST1 and $\beta 1$ integrin, which acts as a receptor for its autocrine/paracrine activity (15). Further evidence for this novel receptor was provided by Lavagno et al, which showed BST1 also interacts with $\beta 1$ and $\beta 2$ integrins at the neutrophil cell surface (32). Based on these data, we investigated the expression of BST1, $\beta 1$ integrin, and $\beta 2$ integrin in mouse macrophage-like Raw264.7 cells by flow cytometry. As
A

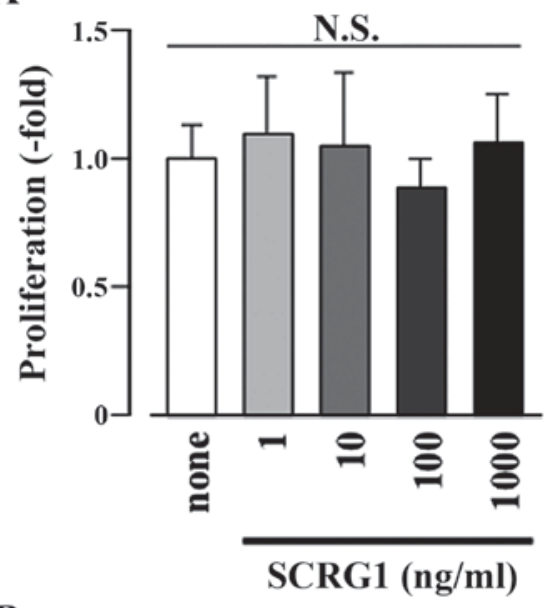

B
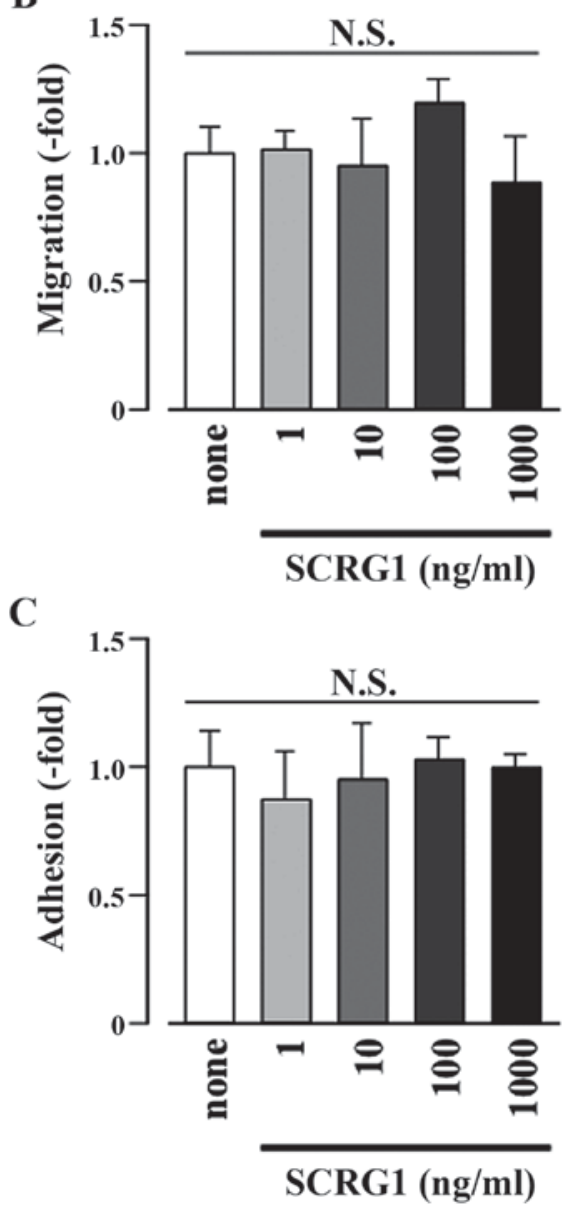

Figure 2. Scrapie responsive gene 1 (SCRG1) did not affect cell proliferation, migration, or adhesion of Raw264.7 cells. Cell proliferation (A), migration (B), and adhesion (C) for Raw264.7 cells were left unstimulated (none) or were stimulated with SCRG1 (1-1,000 $\mathrm{ng} / \mathrm{ml})$. The results are expressed as the fold change relative to the respective control (none). Data are presented as the means \pm SD. ${ }^{*} \mathrm{P}<0.05$ vs. unstimulated control within each cell. N.S., not significant.

shown in Fig. 1, Raw264.7 cells co-expressed BST1, $\beta 1$ integrin, and $\beta 2$ integrin on the cell surface. These results indicate that Raw264.7 cells express the SCRG1 receptor complex.

SCRG1 does not affect the statuses of cell proliferation, migration, and adhesion of Raw264.7 cells. In MSCs, SCRG1 
Table I. Genes whose expression increased more than 100-fold after LPS treatment and less than 100-fold by SCRG1 treatment alone relative to unstimulated Raw264.7 cells.

Fold change relative to unstimulated Raw 264.7 cells

\begin{tabular}{|c|c|c|c|c|}
\hline \multirow[b]{2}{*}{ Gene symbol } & \multirow[b]{2}{*}{ Gene name } & & & \\
\hline & & LPS & LPS+SCRG1 & SCRG1 \\
\hline Ccl22 & Chemokine (C-C motif) ligand 22 & 4420.5 & 1520.1 & 96.335 \\
\hline Ccl8 & Chemokine (C-C motif) ligand 8 & 2856.4 & 1770.5 & 0.84089 \\
\hline Cxcl11 & Chemokine (C-X-C motif) ligand 11 & 1746.1 & 843.35 & 89.884 \\
\hline Ccl12 & Chemokine (C-C motif) ligand 12 & 929.29 & 749.61 & 70.521 \\
\hline Csfl & Colony stimulating factor 1 & 206.50 & 125.36 & 17.876 \\
\hline Cx3cll & Chemokine (C-X3-C motif) ligand 1 & 154.34 & 115.36 & 1.3755 \\
\hline
\end{tabular}

LPS, lipopolysaccharide.

A

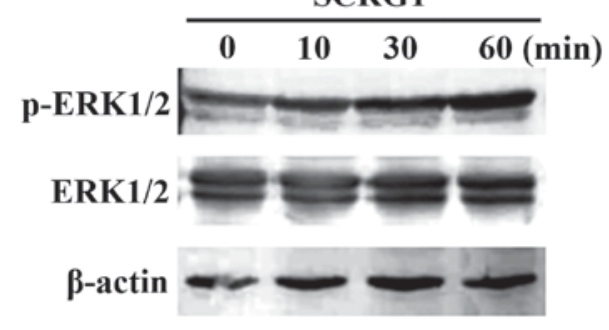

B

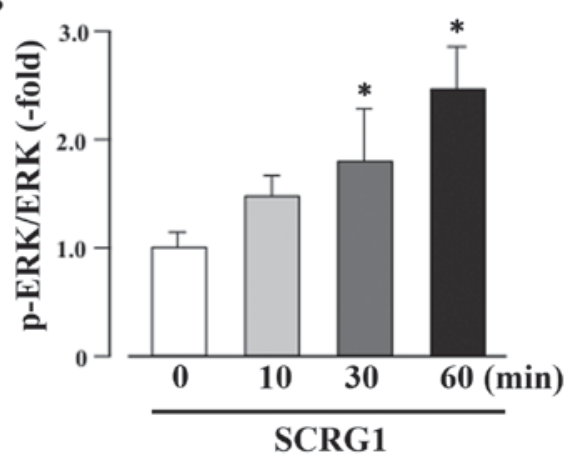

Figure 3. Scrapie responsive gene 1 (SCRG1) enhances the phosphorylation of extracellular signal-regulated kinase 1/2 (ERK1/2) in Raw264.7 cells. (A) ERK1/2 phosphorylation was measured using western blotting with anti-phospho-ERK1/2 (p-ERK1/2) antibodies in Raw264.7 cells stimulated with $100 \mathrm{ng} / \mathrm{ml}$ SCRG1. Total ERK1/2 levels were measured using a primary anti-ERK1/2 (ERK1/2) antibody. As a loading control $\beta$-actin levels were measured using an anti- $\beta$-actin antibody. (B) Densitometry analysis of band intensity in western blotting was expressed as the ratio of phosphorylation to the total molecule. ${ }^{*} \mathrm{P}<0.05$, statistically significant vs. unstimulated control.

promotes cell migration through the $\beta 1$ integrin/focal adhesion kinase (FAK) -dependent phosphoinositide 3-kinase (PI3K)/Akt pathway (15). Here, to understand the biological processes controlled by SCRG1 in macrophages, the effects of SCRG1 on cell proliferation, migration, as well as adhesion activity were investigated. As shown in Fig. 2, rmSCRG1 did not affect proliferative, migratory, or adhesive activities in Raw264.7 cells. Thus, these results indicate that the bioactivity of SCRG1 in monocyte/macrophage lineage cells is different from that in MSCs.
SCRG1 enhances the phosphorylation of ERK1/2 in Raw264.7 cells. The MAPK pathway, in conjunction with the nuclear factor- $\kappa \mathrm{B}(\mathrm{NF}-\kappa \mathrm{B})$ pathway, is closely associated with the macrophage immune response $(33,34)$. Accordingly, the intracellular signaling pathways induced by SCRG1 in Raw264.7 cells were investigated. Treatment of cell for $30 \mathrm{~min}$ with rmSCRG1 significantly enhanced the phosphorylation of ERK1/2 (Fig. 3). In contrast, phosphorylation of FAK, Akt, SAPK/Jun amino-terminal kinase (JNK), or p38 MAPK by rmSCRG1 treatment in Raw264.7 cells was not observed (data not shown). These results indicate that SCRG1 specifically induces the activation of the ERK1/2 pathway.

SCRG1 suppresses LPS-induced CCL22 production through the activation of ERK1/2 in Raw264.7 cells. By primer array analysis, we next investigated the effects of SCRG1 on the expression of LPS-induced chemokines and cytokines in Raw264.7 cells. As shown in Table I, rmSCRG1 suppresses the LPS-induced production of five chemokines and one cytokine in these cells. In particular, LPS-induced $\mathrm{Ccl} 22$ expression was reduced to less than half by rmSCRG1 treatment. Following on from this, we examined the association between suppression of CCL22 expression and ERK activation by rmSCRG1 in Raw264.7 cells. Both the LPS-induced increases in CCL22 mRNA expression, and protein secretion were significantly suppressed by rmSCRG1 treatment in Raw264.7 cells (Fig. 4). In addition, this suppressive effect of rmSCRG1 was completely abolished by treatment with the MAPK/ERK kinase inhibitor, U0126. These results indicate that LPS-induced CCL22 production in macrophages was suppressed by treatment with SCRG1 through the activation of an ERK1/2-mediated signal.

\section{Discussion}

Several roles of SCRG1 suggested in this study and our previous studies are shown in Fig. 5. Recently, we identified a novel ligand-receptor combination, SCRG1/BST1, that maintains expressions of the stem cell markers Oct-4 and CD271/LNGFR in MSC, as well as self-renewal, migration, and osteogenic differentiation potential during ex vivo expansion (15). Here, we investigated the expression of the SCRG1 
A

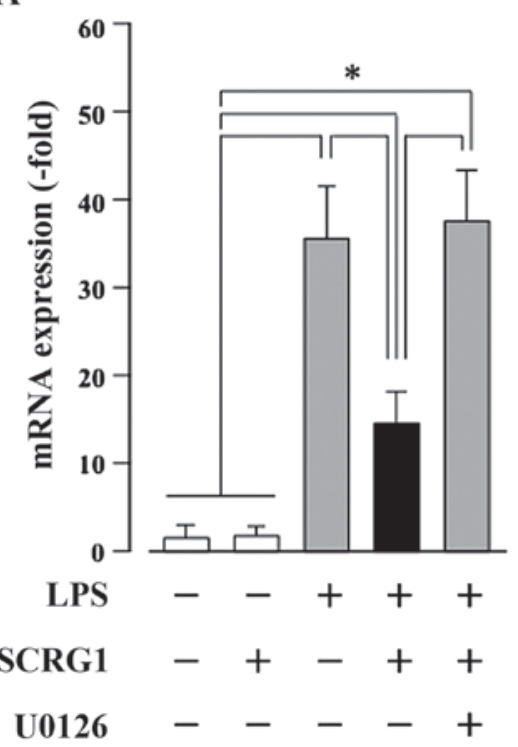

B

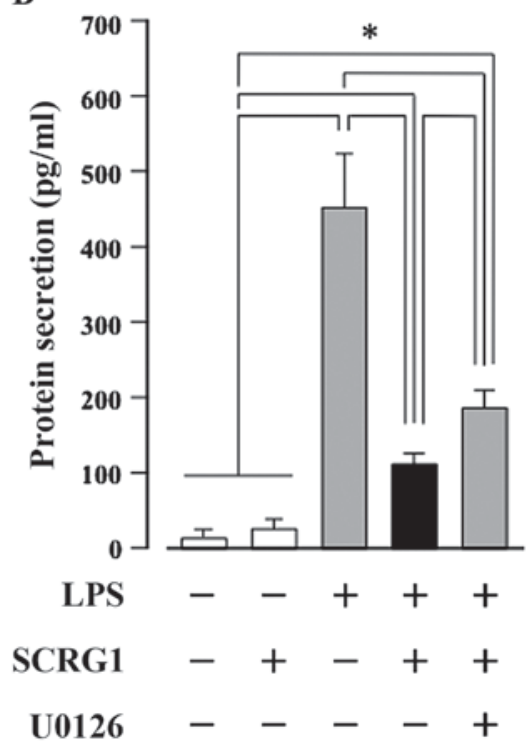

Figure 4. Scrapie responsive gene 1 (SCRG1) suppresses lipopolysaccharide (LPS)-induced CC-chemokine ligand 22 (CCL22) production through the activation of extracellular signal-regulated kinase 1/2 (ERK1/2) in Raw264.7 cells. Raw264.7 cells were stimulated with or without $10 \mathrm{ng} / \mathrm{ml} \mathrm{LPS}, 100 \mathrm{ng} / \mathrm{ml}$ rmSCRG1, and $1 \mathrm{mM} \mathrm{U0126}$ for either $6 \mathrm{~h}$ (A) or $48 \mathrm{~h}$ (B). (A) Reverse transcription-quantitative polymerase chain reaction (RT-qPCR) was performed with specific oligonucleotide primers. mRNA expression level of $C c l 22$ was normalized to glyceraldehyde-3-phosphate dehydrogenase, and the results are expressed as the fold change relative to the unstimulated control. (B) The amount of secreted CCL22 in the culture medium was measured using a sandwich enzyme-linked immunosorbent assay (ELISA) for mouse CCL22. In (A) and (B), data are presented as the means \pm SD. " $\mathrm{P}<0.05$ vs. unstimulated control within each cell.

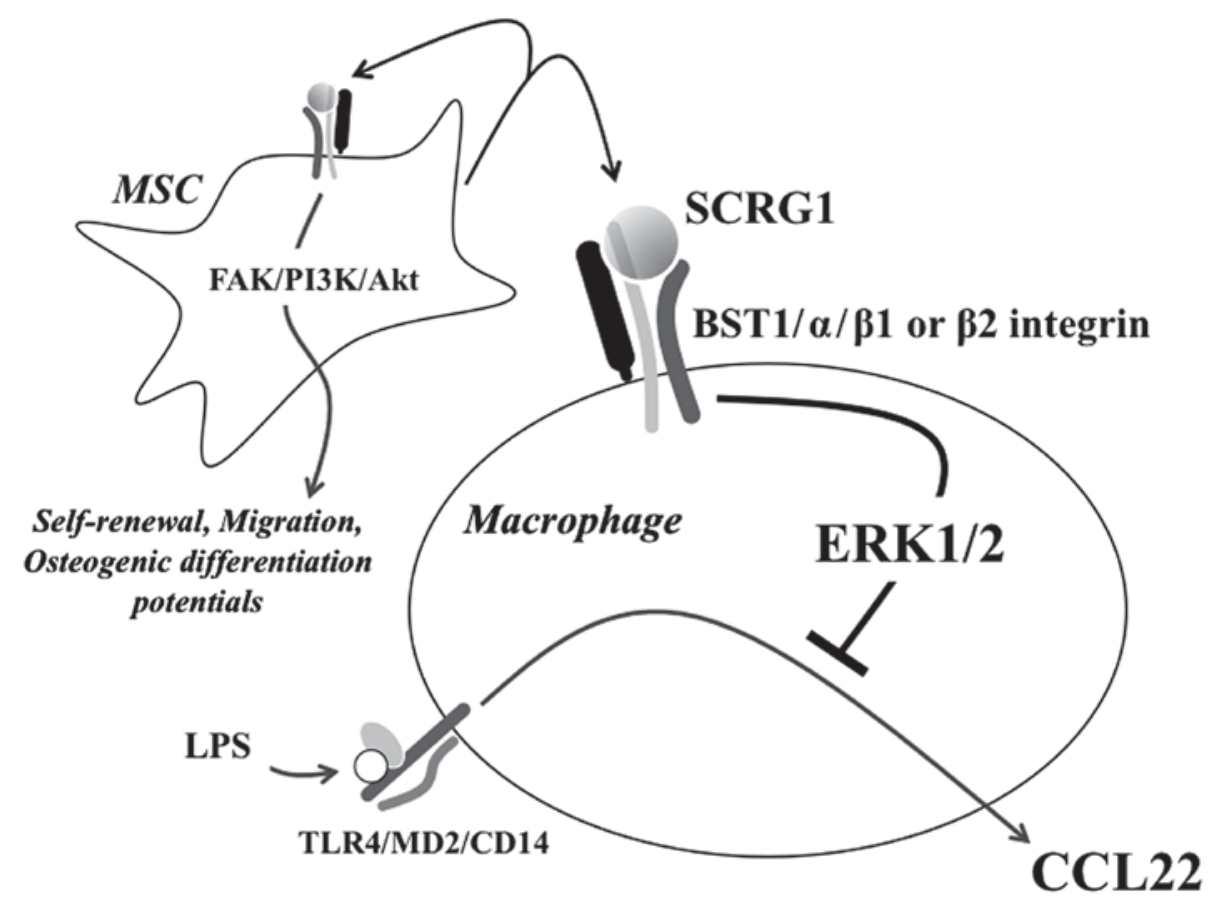

Figure 5. Several roles of scrapie responsive gene 1 (SCRG1) suggested in this study and our previous reports. SCRG1 is hypothesized to be secreted into the extracellular space by mesenchymal sem cells (MSCs) and to have autocrine/paracrine activity. The putative receptor for SCRG1 is a complex of bone marrow stromal cell antigen 1 (BST1) and $\beta 1$ or $\beta 2$ integrins on the cell surface. The SCRG1/BST1 axis positively regulates the self-renewal, migration, and osteogenic differentiation potentials of MSCs through the FAK/PI3 K/Akt signaling pathway. In macrophage, lipopolysaccharide (LPS) interacts with a heterologous receptor involving toll-like receptor 4 (TLR4), CD14, and MD2. SCRG1 suppresses LPS-induced CC-chemokine ligand 22 (CCL22) production of macrophage in a extracellular signal-regulated kinase 1/2 (ERK1/2)-dependent manner.

receptor components, BST1, $\beta 1$ integrin, and $\beta 2$ integrin in mouse macrophage-like Raw264.7 cells. In addition to BST1, these cells also expressed $\beta 1$ and $\beta 2$ integrins (Fig. 1). BST1 is an ectoenzyme with a glycosyl phosphatidylinositol anchor and a NADase/ADP-ribosyl cyclase activity that belongs to the CD38 family $(35,36)$. It has been found on the cell surface of stromal (37) and bone marrow-derived cells (38), and it facilitates pre-B-cell growth and induces cell migration (39). Under 
the condition of a complex of BST1 with either $\beta 1$ integrin or $\beta 2$ integrin, BST1 has been shown to promote the phosphorylation of FAK through the use of an agonistic monoclonal antibody $(32,40,41)$. Furthermore, it has also been reported that BST-1 regulates the adhesion and migration of leukocytes via phosphorylation of Akt and MAPKs $(42,43)$. In this study, we also observed that SCRG1 enhanced the phosphorylation of ERK1/2 in Raw264.7 cells (Fig. 3).

Notably, SCRG1 did not enhance cell proliferation, migration, or adhesion of Raw264.7 cells (Fig. 2), indicating a different biological function in these cells. In support of this, we demonstrated that SCRG1 suppresses LPS-induced CCL22 production in these mouse macrophage-like Raw264.7 cells in a MAPK/ERK-dependent manner (Table I, Fig. 4). LPS and other microbial products are recognized by the host's toll-like receptors (TLRs) family members (44). LPS interacts with a heterologous receptor involving TLR4 $(45,46)$, CD14 $(47,48)$ and MD2 (49-51). By LPS binds to the TLR4, two major signaling pathways via the adapter molecules TIR-domain-containing adaptor inducing IFN- $\beta$ (TRIF) or myeloid differentiation factor 88 (MyD88) are activated (45,52-55). Significantly, both the Myd88 and TRIF pathways result in activation of the transcription factor, $\mathrm{NF}-\kappa \mathrm{B}$, a central regulator of the LPS response, which induces cytokine and chemokine production as well as stress responses in many cell types, including macrophages $(53,54)$. $\mathrm{NF}-\kappa \mathrm{B}$ is involved in regulating the expression of multiple genes involved in inflammatory and immune responses (56). Innate and adaptive immune response are mainly regulated by MAPKs, including ERK, JNK, and p38 MAPK, in addition to the $N F-\kappa B$ pathway. In macrophages, activation of the $\mathrm{MEK} / \mathrm{ERK}$ pathway by bacterial infection regulates various inflammatory responses (57-61). The MEK/ERK pathway is one of the most studied intracellular signaling pathways in monocyte-derived macrophages activated by LPS-induced pro-inflammatory responses (62-64). In addition, findings have been previously reported that $\mathrm{NF}-\kappa \mathrm{B}$-dependent gene expression is controlled by the activation of ERK1/2 without affecting DNA binding (65-69). Therefore, our results indicate that the SCRG1-induced ERK1/2 signaling pathway controls $\mathrm{NF}-\kappa \mathrm{B}$-dependent chemokine CCL22 expression.

CCL22, a member of the CC chemokine families, is mainly produced by monocyte-derived macrophages, mast cells, and inflammatory dendritic cells upon stimulation with microbial products $(70,71)$. CCL22 binds to its receptor CCR4 plays an important homeostatic role in leukocyte trafficking, activation of innate immune cells, Th2 immunopathology, as well as accumulation of regulatory $\mathrm{T}$ (Treg) cells in solid tumor (72-74). CCL 22 also plays a role in recruiting Treg cells into synovial fluid in inflammatory diseases like rheumatoid arthritis (75). CCL22 plays an important role in a variety of other diseases, including allergic rhinitis (76), atopic dermatitis (77), and lymphoma (78). Recent studies suggested that CCL22 can be used as a biomarker for autoimmune diseases (79). On the other hand, the role of CCL 22 in regulation of immune homeostasis is unclear $(80,81)$.

In conclusion, here we clearly demonstrate that SCRG1, which in vivo could be derived from MSCs, suppresses LPS-induced chemokine CCL22 production in Raw264.7 macrophages. The mechanism appears to involve the MAPK
ERK1/2 pathway, since SCRG1 induced the phosphorylation of ERK1/2 and a MAPK/ERK kinase inhibitor U0126 ablated the suppressive effect of SCRG1 on LPS-induced chemokine CCL22 production. These results suggest a model whereby MSCs play their immunosuppressive role by secreting SCRG1, which then suppresses microbial products-induced chemokine expression in monocyte/macrophage lineage cells in a paracrine fashion. We have additionally established fluorescently tagged immortalized MSC lines derived from different tissues of GFP- and tdTomato-transgenic mice $(25,82)$. These cell lines can be used for in vivo imaging analyses on proliferation and differentiation of MSCs, as well as in vivo imaging studies to test cell therapies and regenerative medicine techniques, providing insight into diseases such as bone and immune disorders, fibrosis, and cancer progression or metastasis. Our findings provide new insights into the molecular mechanisms of MSCs, as well as a novel perspective for understanding the immune regulatory mechanisms of MSCs.

\section{Acknowledgements}

The present study was supported in part by the JSPS KAKENHI grant nos. JP25463053 and JP16K11654 awarded to N.C., JP26893249 and JP16K20652 awarded to E.K. and JP26670852 and JP16H05534 awarded to A.I.; and a grant from the Keiryokai Research Foundation grant no. 120 awarded to N.C., 2013.

\section{References}

1. Prockop DJ: Marrow stromal cells as stem cells for nonhematopoietic tissues. Science 276: 71-74, 1997.

2. Uccelli A, Moretta L and Pistoia V: Mesenchymal stem cells in health and disease. Nat Rev Immunol 8: 726-736, 2008.

3. Shi Y, Su J, Roberts AI, Shou P, Rabson AB and Ren G: How mesenchymal stem cells interact with tissue immune responses. Trends Immunol 33: 136-143, 2012.

4. Le Blanc K, Rasmusson I, Sundberg B, Götherström C, Hassan M, Uzunel M and Ringdén O: Treatment of severe acute graft-versus-host disease with third party haploidentical mesenchymal stem cells. Lancet 363: 1439-1441, 2004.

5. Stemberger S, Jamnig A, Stefanova N, Lepperdinger G, Reindl M and Wenning GK: Mesenchymal stem cells in a transgenic mouse model of multiple system atrophy: Immunomodulation and neuroprotection. PLoS One 6: e19808, 2011.

6. Ortiz LA, Dutreil M, Fattman C, Pandey AC, Torres G, Go K and Phinney DG: Interleukin 1 receptor antagonist mediates the antiinflammatory and antifibrotic effect of mesenchymal stem cells during lung injury. Proc Natl Acad Sci USA 104: 11002-11007, 2007.

7. Lee RH, Pulin AA, Seo MJ, Kota DJ, Ylostalo J, Larson BL, Semprun-Prieto L, Delafontaine P and Prockop DJ: Intravenous hMSCs improve myocardial infarction in mice because cells embolized in lung are activated to secrete the anti-inflammatory protein TSG-6. Cell Stem Cell 5: 54-63, 2009.

8. Tögel F, Hu Z, Weiss K, Isaac J, Lange $\mathrm{C}$ and Westenfelder C: Administered mesenchymal stem cells protect against ischemic acute renal failure through differentiation-independent mechanisms. Am J Physiol Renal Physiol 289: F31-F42, 2005.

9. Sheikh AM, Nagai A, Wakabayashi K, Narantuya D, Kobayashi S, Yamaguchi S and Kim SU: Mesenchymal stem cell transplantation modulates neuroinflammation in focal cerebral ischemia: Contribution of fractalkine and IL-5. Neurobiol Dis 41: 717-724, 2011.

10. Lee JK, Jin HK, Endo S, Schuchman EH, Carter JE and Bae JS: Intracerebral transplantation of bone marrow-derived mesenchymal stem cells reduces amyloid-beta deposition and rescues memory deficits in Alzheimer's disease mice by modulation of immune responses. Stem Cells 28: 329-343, 2010. 
11. Meirelles Lda S, Fontes AM, Covas DT and Caplan AI: Mechanisms involved in the therapeutic properties of mesenchymal stem cells. Cytokine Growth Factor Rev 20: 419-427, 2009.

12. Di Nicola M, Carlo-Stella C, Magni M, Milanesi M, Longoni PD, Matteucci P, Grisanti S and Gianni AM: Human bone marrow stromal cells suppress T-lymphocyte proliferation induced by cellular or nonspecific mitogenic stimuli. Blood 99: 3838-3843, 2002

13. Ooi YY, Ramasamy R, Rahmat Z, Subramaiam H, Tan SW, Abdullah M, Israf DA and Vidyadaran S: Bone marrow-derived mesenchymal stem cells modulate BV2 microglia responses to lipopolysaccharide. Int Immunopharmacol 10: 1532-1540, 2010.

14. Németh K, Leelahavanichkul A, Yuen PS, Mayer B, Parmelee A, Doi K, Robey PG, Leelahavanichkul K, Koller BH,Brown JM, et al: Bone marrow stromal cells attenuate sepsis via prostaglandin $\mathrm{E}(2)$-dependent reprogramming of host macrophages to increase their interleukin-10 production. Nat Med 15: 42-49, 2009.

15. Aomatsu E, Takahashi N, Sawada S, Okubo N, Hasegawa T, Taira M, Miura H, Ishisaki A and Chosa N: Novel SCRG1/BST1 axis regulates self-renewal, migration, and osteogenic differentiation potential in mesenchymal stem cells. Sci Rep 4: 3652, 2014.

16. Dandoy-Dron F, Guillo F, Benboudjema L, Deslys JP, Lasmézas C, Dormont D, Tovey MG and Dron M: Gene expression in scrapie. Cloning of a new scrapie-responsive gene and the identification of increased levels of seven other mRNA transcripts. J Biol Chem 273: 7691-7697, 1998.

17. Dron M, Bailly Y, Beringue V, Haeberlé AM, Griffond B, Risold PY, Tovey MG, Laude H and Dandoy-Dron F: Scrg1 is induced in TSE and brain injuries and associated with autophagy. Eur J Neurosci 22: 133-146, 2005.

18. Dron M, Bailly Y, Beringue V, Haeberlé AM, Griffond B, Risold PY, Tovey MG, Laude H and Dandoy-Dron F: SCRG1, a potential marker of autophagy in transmissible spongiform encephalopathies. Autophagy 2: 58-60, 2006.

19. Dron M, Dandoy-Dron F, Guillo F, Benboudjema L, Hauw JJ, Lebon P, Dormont D and Tovey MG: Characterization of the human analogue of a Scrapie-responsive gene. J Biol Chem 273 $18015-18018,1998$.

20. Dron M, Tartare X, Guillo F, Haik S, Barbin G, Maury C, Tovey $\mathrm{M}$ and Dandoy-Dron F: Mouse scrapie responsive gene 1 (Scrg1): Genomic organization, physical linkage to sap30, genetic mapping on chromosome 8 and expression in neuronal primary cell cultures. Genomics 70: 140-149, 2000.

21. Aggarwal S and Pittenger MF: Human mesenchymal stem cells modulate allogeneic immune cell responses. Blood 105 1815-1822, 2005

22. Spaggiari GM, Capobianco A, Abdelrazik H, Becchetti F, Mingari MC and Moretta L: Mesenchymal stem cells inhibit natural killer-cell proliferation, cytotoxicity and cytokine production: Role of indoleamine 2,3-dioxygenase and prostaglandin E2. Blood 111: 1327-1333, 2008.

23. Sato K, Ozaki K, Oh I, Meguro A, Hatanaka K, Nagai T, Muroi K and Ozawa K: Nitric oxide plays a critical role in suppression of T-cell proliferation by mesenchymal stem cells. Blood 109 : 228-234, 2007

24. Lee RH, Oh JY, Choi H and Bazhanov N: Therapeutic factors secreted by mesenchymal stromal cells and tissue repair. J Cell Biochem 112: 3073-3078, 2011

25. Sawada S, Chosa N, Takizawa N, Yokota J, Igarashi Y, Tomoda K, Kondo H, Yaegashi T and Ishisaki A: Establishment of mesenchymal stem cell lines derived from the bone marrow of green fluorescent protein-transgenic mice exhibiting a diversity in intracellular transforming growth factor- $\beta$ and bone morphogenetic protein signaling. Mol Med Rep 13: 2023-2031,2016.

26. Igarashi $Y$, Chosa N, Sawada S, Kondo H, Yaegashi $T$ and Ishisaki A: VEGF-C and TGF- $\beta$ reciprocally regulate mesenchymal stem cell commitment to differentiation into lymphatic endothelial or osteoblastic phenotypes. Int J Mol Med 37: $1005-1013,2016$

27. Godiska R, Chantry D, Raport CJ, Sozzani S, Allavena P, Leviten D, Mantovani A and Gray PW: Human macrophage-derived chemokine (MDC), a novel chemoattractant for monocytes, monocyte-derived dendritic cells and natural killer cells. J Exp Med 185: 1595-1604, 1997.

28. Chang Ms, McNinch J, Elias C III, Manthey CL, Grosshans D, Meng T, Boone T and Andrew DP: Molecular cloning and functional characterization of a novel CC chemokine, stimulated $\mathrm{T}$ cell chemotactic protein (STCP-1) that specifically acts on activated T lymphocytes. J Biol Chem 272: 25229-25237, 1997.
29. Schaniel C, Pardali E, Sallusto F, Speletas M, Ruedl C, Shimizu T, Seidl T, Andersson J, Melchers F, Rolink AG and Sideras P: Activated murine B lymphocytes and dendritic cells produce a novel CC chemokine which acts selectively on activated T cells J Exp Med 188: 451-463, 1998.

30. Mantovani A, Gray PA, Van Damme J and Sozzani S: Macrophage-derived chemokine (MDC). J Leukoc Biol 68: 400-404, 2000.

31. Livak KJ and Schmittgen TD: Analysis of relative gene expression data using real-time quantitative PCR and the 2(-Delta Delta C(T)) Method. Methods 25: 402-408, 2001.

32. Lavagno L, Ferrero E, Ortolan E, Malavasi F and Funaro A: CD157 is part of a supramolecular complex with CD11b/CD18 on the human neutrophil cell surface. J Biol Regul Homeost Agents 21: 5-11, 2007

33. Arthur JS and Ley SC: Mitogen-activated protein kinases in innate immunity. Nat Rev Immunol 13: 679-692, 2013

34. Huang G, Shi LZ and Chi H: Regulation of JNK and p38 MAPK in the immune system: Signal integration, propagation and termination. Cytokine 48: 161-169, 2009.

35. Ishihara $\mathrm{K}$ and Hirano T: BST-1/CD157 regulates the humoral immune responses in vivo. Chem Immunol 75: 235-255, 2000.

36. Malavasi F, Deaglio S, Funaro A, Ferrero E, Horenstein AL, Ortolan E, Vaisitti T and Aydin S: Evolution and function of the ADP ribosyl cyclase/CD38 gene family in physiology and pathology. Physiol Rev 88: 841-886, 2008.

37. Kaisho T, Ishikawa J, Oritani $\mathrm{K}$, Inazawa $J$, Tomizawa $H$, Muraoka O, Ochi T and Hirano T: BST-1, a surface molecule of bone marrow stromal cell lines that facilitates pre-B-cell growth. Proc Natl Acad Sci USA 91: 5325-5329, 1994.

38. Goldstein SC and Todd RF III: Structural and biosynthetic features of the Mo5 human myeloid differentiation antigen. Tissue Antigens 41: 214-218, 1993.

39. Funaro A, Ortolan E, Bovino P, Lo Buono N, Nacci G, Parrotta R, Ferrero E and Malavasi F: Ectoenzymes and innate immunity: The role of human CD157 in leukocyte trafficking. Front Biosci (Landmark Ed) 14: 929-943, 2009.

40. Hussain AM, Lee HC and Chang CF: Functional expression of secreted mouse BST-1 in yeast. Protein Expr Purif 12 133-137, 1998.

41. Okuyama Y, Ishihara K, Kimura N, Hirata Y, Sato K, Itoh M, Ok LB and Hirano T: Human BST-1 expressed on myeloid cells functions as a receptor molecule. Biochem Biophys Res Commun 228: 838-845, 1996

42. Lo Buono N, Parrotta R, Morone S, Bovino P, Nacci G, Ortolan E, Horenstein AL, Inzhutova A, Ferrero E and Funaro A: The CD157-integrin partnership controls transendothelial migration and adhesion of human monocytes. J Biol Chem 286 18681-18691, 2011

43. Funaro A, Ortolan E, Ferranti B, Gargiulo L, Notaro R, Luzzatto L and Malavasi F: CD157 is an important mediator of neutrophil adhesion and migration. Blood 104: 4269-4278, 2004.

44. Takeda K, Kaisho T and Akira S: Toll-like receptors. Annu Rev Immunol 21: 335-376, 2003

45. Poltorak A, He X, Smirnova I, Liu MY, Van Huffel C, Du X, Birdwell D, Alejos E, Silva M, Galanos C, et al: Defective LPS signaling in $\mathrm{C} 3 \mathrm{H} / \mathrm{HeJ}$ and $\mathrm{C} 57 \mathrm{BL} / 10 \mathrm{ScCr}$ mice: Mutations in Tlr4 gene. Science 282: 2085-2088, 1998.

46. Qureshi ST, Larivière L, Leveque G, Clermont S, Moore KJ, Gros P and Malo D: Endotoxin-tolerant mice have mutations in Toll-like receptor 4 (Tlr4). J Exp Med 189: 615-625, 1999.

47. Wright SD: CD14 and innate recognition of bacteria. J Immunol 155: 6-8, 1995.

48. Ulevitch RJ and Tobias PS: Receptor-dependent mechanisms of cell stimulation by bacterial endotoxin. Annu Rev Immunol 13: 437-457, 1995.

49. Shimazu R, Akashi S, Ogata H, Nagai Y, Fukudome K, Miyake K and Kimoto M: MD-2, a molecule that confers lipopolysaccharide responsiveness on toll-like receptor 4. J Exp Med 189: 1777-1782, 1999.

50. Akashi S, Shimazu R, Ogata H, Nagai Y, Takeda K, Kimoto M and Miyake K: Cutting edge: Cell surface expression and lipopolysaccharide signaling via the toll-like receptor 4-MD-2 complex on mouse peritoneal macrophages. J Immunol 164: 3471-3475, 2000

51. Viriyakosol S, Tobias PS, Kitchens RL and Kirkland TN: MD-2 binds to bacterial lipopolysaccharide. J Biol Chem 276: 38044-38051, 2001. 
52. O'Neill LA, Dunne A, Edjeback M, Gray P, Jefferies C and Wietek C: Mal and MyD88: Adapter proteins involved in signal transduction by toll-like receptors. J Endotoxin Res 9: 55-59, 2003.

53. Kawai T, Adachi O, Ogawa $\mathrm{T}$, Takeda $\mathrm{K}$ and Akira $\mathrm{S}$. Unresponsiveness of MyD88-deficient mice to endotoxin. Immunity 11: 115-122, 1999.

54. Kawai T, Takeuchi O, Fujita T, Inoue J, Mühlradt PF, Sato S, Hoshino $\mathrm{K}$ and Akira S: Lipopolysaccharide stimulates the MyD88-independent pathway and results in activation of IFN-regulatory factor 3 and the expression of a subset of lipopolysaccharide-inducible genes. J Immunol 167: 5887-5894, 2001

55. West AP, Koblansky AA and Ghosh S: Recognition and signaling by toll-like receptors. Annu Rev Cell Dev Biol 22: 409-437, 2006.

56. Ghosh $\mathrm{S}$ and Karin M: Missing pieces in the NF-kappaB puzzle. Cell 109: S81-S96, 2002.

57. Gordon S and Martinez FO: Alternative activation of macrophages: Mechanism and functions. Immunity 32: 593-604, 2010

58. Nathan C: Points of control in inflammation. Nature 420 : 846-852, 2002.

59. Mantovani A, Sica A, Sozzani S, Allavena P, Vecchi A and Locati M: The chemokine system in diverse forms of macrophage activation and polarization. Trends Immunol 25: 677-686, 2004.

60. Nathan C and Ding A: Nonresolving inflammation. Cell 140: $871-882,2010$

61. Martinez FO, Gordon S, Locati M and Mantovani A Transcriptional profiling of the human monocyte-to-macrophage differentiation and polarization: New molecules and patterns of gene expression. J Immunol 177: 7303-7311, 2006.

62. Rao KM: MAP kinase activation in macrophages. J Leukoc Biol 69: 3-10, 2001.

63. Rao KM, Meighan T and Bowman L: Role of mitogen-activated protein kinase activation in the production of inflammatory mediators: Differences between primary rat alveolar macrophages and macrophage cell lines. J Toxicol Environ Health A 65: 757-768, 2002.

64. Bain J, Plater L, Elliott M, Shapiro N, Hastie CJ, McLauchlan H, Klevernic I, Arthur JS, Alessi DR and Cohen P: The selectivity of protein kinase inhibitors: A further update. Biochem J 408: 297-315, 2007.

65. Akhtar M, Watson JL, Nazli A and McKay DM: Bacterial DNA evokes epithelial IL-8 production by a MAPK-dependent, NF-kappaB-independent pathway. FASEB J 17: 1319-1321, 2003.

66. Fiebich BL, Schleicher S, Butcher RD, Craig A and Lieb K The neuropeptide substance $\mathrm{P}$ activates $\mathrm{p} 38$ mitogen-activated protein kinase resulting in IL-6 expression independently from NF-kappa B. J Immunol 165: 5606-5611, 2000

67. Patel DN, King CA, Bailey SR, Holt JW, Venkatachalam K, Agrawal A, Valente AJ and Chandrasekar B: Interleukin-17 stimulates C-reactive protein expression in hepatocytes and smooth muscle cells via p38 MAPK and ERK1/2-dependent NF-kappaB and C/EBPbeta activation. J Biol Chem 282: 27229-27238, 2007.

68. Tokuda M, Miyamoto R, Sakuta T, Nagaoka S and Torii M: Substance P activates p38 mitogen-activated protein kinase to promote IL-6 induction in human dental pulp fibroblasts. Connect Tissue Res 46: 153-158, 2005.

69. Zampetaki A, Mitsialis SA, Pfeilschifter J and Kourembanas S: Hypoxia induces macrophage inflammatory protein-2 (MIP-2) gene expression in murine macrophages via NF-kappaB: The prominent role of p42/p44 and PI3 kinase pathways. FASEB J 18 1090-1092, 2004.
70. Yamashita U and Kuroda E: Regulation of macrophage-derived chemokine (MDC, CCL22) production. Crit Rev Immunol 22: 105-114, 2002.

71. Layseca-Espinosa E, Korniotis S, Montandon R, Gras C, Bouillié M, Gonzalez-Amaro R, Dy $M$ and Zavala $F$. CCL22-producing CD $8 \alpha$ - myeloid dendritic cells mediate regulatory $\mathrm{T}$ cell recruitment in response to G-CSF treatment. J Immunol 191: 2266-2272, 2013.

72. Iellem A, Mariani M, Lang R, Recalde H, Panina-Bordignon $P$, Sinigaglia F and D'Ambrosio D: Unique chemotactic response profile and specific expression of chemokine receptors CCR4 and CCR 8 by CD4(+)CD25(+) regulatory T cells. J Exp Med 194: 847-853, 2001.

73. Curiel TJ, Coukos G, Zou L, Alvarez X, Cheng P, Mottram P, Evdemon-Hogan M, Conejo-Garcia JR, Zhang L, Burow M, et al: Specific recruitment of regulatory $\mathrm{T}$ cells in ovarian carcinoma fosters immune privilege and predicts reduced survival. Nat Med 10: 942-949, 2004.

74. Li YQ, Liu FF, Zhang XM, Guo XJ, Ren MJ and Fu L: Tumor secretion of CCL22 activates intratumoral treg infiltration and is independent prognostic predictor of breast cancer. PLoS One 8: e76379, 2013.

75. Flytlie HA, Hvid M, Lindgreen E, Kofod-Olsen E, Petersen EL, Jørgensen A, Deleuran M, Vestergaard C and Deleuran B: Expression of MDC/CCL22 and its receptor CCR4 in rheumatoid arthritis, psoriatic arthritis and osteoarthritis. Cytokine 49: 24-29, 2010.

76. Yanai M, Sato K, Aoki N, Takiyama Y, Oikawa K, Kobayashi H, Kimura S, Harabuchi Y and Tateno M: The role of CCL22/macrophage-derived chemokine in allergic rhinitis. Clin Immunol 125: 291-298, 2007.

77. Nakazato J, Kishida M, Kuroiwa R, Fujiwara J, Shimoda M and Shinomiya N: Serum levels of Th2 chemokines, CCL17, CCL22 and CCL27, were the important markers of severity in infantile atopic dermatitis. Pediatr Allergy Immunol 19: 605-613, 2008.

78. Niens M, Visser L, Nolte IM, van der Steege G, Diepstra A, Cordano P, Jarrett RF, Te Meerman GJ, Poppema S and van den Berg A: Serum chemokine levels in hodgkin lymphoma patients: Highly increased levels of CCL17 and CCL22. Br J Haematol 140: $527-536,2008$

79. Jafarzadeh A, Ebrahimi HA, Bagherzadeh S, Zarkesh F, Iranmanesh F, Najafzadeh A, Khosravimashizi A, Nemati M, Sabahi A, Hajghani H, et al: Lower serum levels of Th2-related chemokine CCL22 in women patients with multiple sclerosis: A comparison between patients and healthy women. Inflammation 37: 604-610, 2014

80. Nagata S: Apoptosis and autoimmune diseases. Ann N Y Acad Sci 1209: 10-16, 2010.

81. Szondy Z, Garabuczi E, Joós G, Tsay GJ and Sarang Z: Impaired clearance of apoptotic cells in chronic inflammatory diseases: Therapeutic implications. Front Immunol 5: 354, 2014.

82. Furukawa S, Kuwajima Y, Chosa N, Satoh K, Ohtsuka M, Miura H, Kimura M, Inoko H, Ishisaki A, Fujimura A and Miura H: Establishment of immortalized mesenchymal stem cells derived from the submandibular glands of td to mato transgenic mice. Exp Ther Med 10: 1380-1386, 2015. 